\title{
A população do Brasil, 1570-1700: uma revisão historiográfica
}

\author{
Angelo Alves Carrara[1]
}

\begin{abstract}
Resumo
Este artigo passa em revista a historiografia relativa às estimativas de população do Brasil para o período de 1570 até o alvorecer do século XVIII, com especial atenção ao autor que se tornou a referência de quase todos os estudos, Contreiras Rodrigues. O trabalho também busca confrontar os dados com outras fontes disponíveis - como as fontes fiscais - , bem como aferir a validade das estimativas propostas.
\end{abstract}

Palavras-chave: Brasil Colônia; população; historiografia.

\section{La población de Brasil, 1570-1700: una revisión historiográfica}

\section{Resumen}

Este artículo revisa la historiografía sobre las estimaciones de población de Brasil para el período de 1570 hasta los albores del siglo 18, con especial atención al autor que se convirtió en la referencia de casi todos los estudios, Contreiras Rodrigues. El trabajo también busca comparar datos con otras fuentes disponibles - como las fuentes tributarias - , así como evaluar la validez de las estimaciones propuestas.

Palabras clave: Brasil Colonia; población; historiografía.

\section{The population of Brazil, 1570-1700: a historiographical review}

\section{Abstract}

This article reviews the historiography of Brazil's population estimates for the period from 1570 until the beginning of the $18^{\text {th }}$ century, with special attention to Contreiras Rodrigues, whose work became a benchmark for nearly all studies. The article also aims to compare the data with other available sources, such as tax sources, as well as to assess the validity of the proposed estimates.

Keywords: colonial Brazil; population; historiography.

\section{La population du Brésil, 1570-1700: une révision historiographique}

\section{Résumé}

Cet article recapitule l'historiographie concernant l'estimations de la population du Brésil de 1570 jusquà l'aube du XVIIIe siècle, en étant particulièrement attentif à l'auteur qui est devenu référence dans les études, Contreiras Rodrigues. On cherche de comparer lês donnés avec d'autres sources par exemple, les sources fiscales -, et de valider les estimations proposées.

Mots-clés: Brésil colonial; population; historiographie. 
s estimativas da população do Brasil para os séculos XVI e XVII atualmente consideradas válidas são baseadas nos dados apresentados por Roberto Simonsen a partir de cálculos elaborados por Félix Contreiras Rodrigues. Para 1690, contudo, Simonsen diverge um pouco de sua fonte e apresenta uma média entre os números propostos por Contreiras Rodrigues para 1660 (184 mil) e 1700 (300 mil), isto é, 242 mil habitantes. Estas são as cifras incluídas pelo Instituto Brasileiro de Geografia e Estatística nas Estatísticas históricas do Brasil e replicadas amplamente. ${ }^{1}$ Pretende-se aqui proceder a uma análise do cálculo e dos resultados propostos pelo próprio Contreiras Rodrigues, bem como aferir sua validade.

As fontes de Contreiras Rodrigues são as seguintes:

1. para 1570, as fontes são os capítulos um a nove do Tratado da terra do Brasil, de Pero de Magalhães Gândavo. O autor toma os dados de Gândavo por meio de um artigo de Sílvio Ferreira Rangel publicado na Revista do Instituto Histórico e Geográfico Brasileiro (tomo especial, parte 4). Há, contudo, ligeira divergência para a capitania de Porto Seguro: Contreiras dá o total de 200 (e não 220, como originalmente em Gândavo), o que não altera de modo significativo o total correto de 3.440 vizinhos; Contreiras atribui a cada fogo ("vizinho", no original) cinco pessoas, o que perfaz um total de 17.200 habitantes de origem portuguesa; ${ }^{2}$

2. para 1585, a fonte é Anchieta, mas que igualmente chegou-lhe de forma indireta. O método é o mesmo adotado antes: multiplica-se por cinco o número de vizinhos de origem portuguesa apresentados por Anchieta

'Roberto Simonsen, História econômica do Brasil, 6. ed., São Paulo, Companhia Editora Nacional, 1969, p. 221; Félix Contreiras Rodrigues, Traços da economia social e politica do Brasil colonial, Rio de Janeiro, Ariel, 1935, p. 31-34; Instituto Brasileiro de Geografia e Estatística, Estatísticas históricas do Brasil, 2. ed., Rio de Janeiro, IBGE, 1990, p. 30. A cifra de 300 mil habitantes na virada do século XVII para o XVIII, proposta por Contreiras Rodrigues, consagrou-se ao longo do tempo em estudos como os seguintes: Maria Luiza Marcílio, “Évolution historique de la population brésilienne jusqu'en 1872", In: Committee for International Cooperation in National Research Demography, La population du Brésil, Paris, Committee for International Cooperation in National Research Demography, 1974, p. 7-27 (p. 10: "the best estimates for the total population of Brazil in 1550, 1600 and 1660, drawn from a variety of sources, are still to be found in Félix Contreiras Rodrigues"); Idem, "The population of colonial Brazil", In: Leslie Bethell (ed.). The Cambridge History of Latin America, Cambridge, Cambridge University Press, 1984, p. 37-63 (Colonial Latin America, vol. 2); Maria Beatriz Nizza da Silva, "A população", In: Harold Johnson; Maria Beatriz Nizza da Silva (coords.), O império luso-brasileiro, 15001620, Lisboa, Estampa, 1992, p. 305-333; Clotilde Andrade Paiva; José Alberto Magno de Carvalho; Valéria da Motta Leite, "Demografia", In: Instituto Brasileiro de Geografia e Estatística, Estatísticas históricas do Brasil, 2. ed., Rio de Janeiro, IBGE, 1990, p. 19-52. Por sua vez, as cifras reproduzidas por Simonsen (1969) e Marcílio (1984) foram igualmente tomadas recentemente por Angus Maddison, The world economy, vol. 1, Paris, OECD Publishing, 2006, p. 234-235

${ }^{2} \mathrm{Com}$ relação ao emprego do termo "vizinho", Teresa Rodrigues assinala que os conceitos de morador, vizinho e fogo são utilizados nas fontes quinhentistas, "sem que conheçamos exactamente o seu significado e, por maioria de razões, a sua equivalência quantitativa. Ainda menos se existiu por parte dos agentes responsáveis pela contabilização uniformidade de critérios. Muito se tem falado sobre o coeficiente mais correcto para estimar, a partir desses conceitos, o total de população. Para João Alves Dias, este último deverá situar-se entre 4 e 5, resultado a que chega após várias análises a documentação coeva. No século XVII utilizam-se para além destes os conceitos de almas, pessoas de comunhão, menores de confissão, menores de comunhão, nestes últimos casos correspondendo de forma mais clara a critérios etários, o que permite uma percepção e estimativa populacional de recrutáveis no país". Teresa Rodrigues, Portugal nos séculos XVI e XVII: vicissitudes da dinâmica demográfica, Porto, Centro de Estudos da População, Economia e Sociedade, 2004 (working paper - primeira versão sobre a história da população portuguesa nos séculos XVI e XVII - investigação realizada no âmbito do projecto POCI/DEM/57987/2004 "História da População Portuguesa: das grandes permanências à conquista da modernidade, p. 16-17"). 
(5.595), somando-os ao total de escravos africanos (13.000) e índios cristãos (17.500), o que totaliza 57.600 habitantes para todo o Brasil. O problema está em que, para Pernambuco, há o total de oito mil brancos correspondentes a mil vizinhos; para a Bahia, seus totais de oito mil escravos africanos e quatro mil índios também são incongruentes com as cifras de Anchieta; para Ilhéus, Porto Seguro, Espírito Santo e Rio de Janeiro, o total de portugueses que apresenta é de 750 por capitania. Os 4.500 índios para o Espírito Santo e os três mil do Rio de Janeiro estão acordes com Anchieta. Também não fica claro com base em quê Contreiras Rodrigues atribui o total mil escravos africanos na capitania de São Vicente;

3. para 1600, Contreiras Rodrigues toma dados de Rocha Pombo, que dá para os brancos o total de 30 mil e, para mestiços, negros e índios, 70 mil; aqui, a fonte é extremamente duvidosa, seja pela absoluta ausência de referências, seja pela fragilidade das afirmações. Um rápido exemplo: sobre o Espírito Santo, Rocha Pombo assinalou que "por princípios do século XVII, já havia por ali muitos engenhos" e que Vitória, "por 1600, conta cerca de 700 habitantes". O que diferentes fontes atestam é que o Espírito Santo, até 1629, não tinha mais de oito engenhos; ${ }^{3}$

4. para a população dos meados do século XVII e "segundo várias fontes", o autor arrisca - estas são suas palavras — um total de 184.100 pessoas, assim decomposto: Maranhão e Grão-Pará (entre brancos e índios livres, índios mansos de Marajó) — 40 mil; Ceará — cem; Recife — dois mil portugueses e 15 mil escravos; Olinda - 3.500 portugueses e cinco mil escravos; Salvador e Recôncavo — dez mil portugueses e 30 mil escravos; Ilhéus e Espírito Santo — mil portugueses; Rio e Guanabara - 3.500 portugueses; São Vicente - quatro mil portugueses e 60 mil escravos. De todas essas cifras, a que de longe causa estupefação é o total de 60 mil escravos em São Vicente. Parece muito claro que o autor tomou esse número de uma passagem de Rocha Pombo, relativa ao assalto que, em 1629, se fez às reduções jesuíticas no sul: "em menos de três anos venderamse para as capitanias do norte mais de 60.000 escravos". Esse número por si só representaria um terço do total da população brasileira na época;

5. por fim,

quanto à população em 1690, época das primeiras descobertas de minas de ouro, ou 30 anos após a última estimação demográfica, em face da crise de carestia que afligia o velho mundo, não será exagero agregar aos 184.000 habitantes em 1660, 100.000 advenidiços e mestiços, que dariam, para esse assinalado momento da nossa história, um total de 284.000 a 300.000 habitantes. $^{5}$

Conclusão inevitável: as cifras de Contreiras Rodrigues para o século XVII não são minimamente aceitáveis. Pois bem: o estudo da demografia colonial

${ }^{3}$ José Francisco da Rocha Pombo, História do Brasil, vol. 2, Rio de Janeiro, W. M. Jackson, 1942, p. 56; o total de engenhos é apresentado por Stuart B. Schwartz, Segredos internos, São Paulo, Companhia das Letras, 1988, p. 148. ${ }^{4}$ José Francisco da Rocha Pombo, op cit., p. 68-69.

${ }^{5}$ Félix Contreiras Rodrigues, Traços da economia social e política do Brasil colonial, Rio de Janeiro, Ariel, 1935, p. 34. 
do Estado do Brasil no século XVII tem de levar em consideração três variáveis fundamentais: a população portuguesa, a economia açucareira, responsável pela quase totalidade da demanda de escravos africanos, e a capacidade de incorporação de índios à sociedade colonial.

Com relação à população portuguesa, há de se concordar com Teresa Rodrigues quanto a que, mais que números, reconhecidamente de muito difícil utilização, "importa destacar as linhas de tendência de crescimento populacional". Ainda que disponíveis algumas cifras, as divergências persistem, dada a impossibilidade de "afirmar em segurança qual a correspondência entre fogo, vizinho, morador e ocupantes. Os quais variam entre 3,85 e 4,6".

A autora apresenta duas hipóteses que têm em comum o fato de que o período de 1580 a 1620 assiste a uma desaceleração do crescimento demográfico português, a que se segue, entre 1620 e 1665, uma diminuição ou estagnação. A partir da década de 1660 até o princípio do século XVIII, o crescimento teria ocorrido a uma taxa média de $0,43 \%$. Os Seiscentos foram marcados por fatores que se conjugaram para reduzir a dinâmica demográfica: instabilidade política, alterações climáticas e maus anos agrícolas, bem como importação de doenças contagiosas e mortíferas.

Testemunha desse panorama em meados do século XVII, Manuel Severim de Faria (1583-1655), em capítulo cujo título sugestivo é "como a gente naturalmente se multiplica, e a deste Reino se vai diminuindo do ano de 500 a esta parte, e as causas porquê", afirmou:

das nossas colônias das Ilhas Terceiras e Madeira foi socorrido este Reino por vezes com gente e com cavalos, e com muito trigo. De Angola se tem tirado inumerável gente, que serve não somente nos engenhos do Brasil, mas ainda neste Reino, assim na cultivação do campo, como no serviço ordinário. Da povoação do Brasil resultou a mercancia do açúcar em tanta abundância, que dele provemos quase toda [a] Europa. Donde se vê que estas colônias não nos são de tanto prejuízo, porque nos levam menos gente. Porém na conquista da Índia não sucedeu assim; porque estando tantas mil léguas distante de Portugal, e com navegação tão perigosa, foi necessário tirar-se do Reino muita gente, tornando pouca ou nenhuma dela, porque se intentaram povoar muitas cidades postas nas fronteiras dos mais poderosos príncipes do oriente. ${ }^{?}$

Como se vê, em sua avaliação, o Brasil não estava na lista dos responsáveis pela redução da população portuguesa, que, em 1640, seria igual à encontrada em 1527-1532. Em termos comparativos, a população do Brasil estava muito aquém da de outras porções colonizadas. Na Madeira, a população teria atingido, em 1550, 200 mil habitantes, dos quais três mil eram escravos. No início do século XVII, a população da ilha estabilizara-se em consequência das dificuldades econômicas, convertendo-se em zona de saída. Em termos relativos,

${ }_{6}^{6}$ Teresa Rodrigues, Portugal nos séculos XVI XVVI: vicissitudes da dinâmica demográfica, Porto, Centro de Estudos da População, Economia e Sociedade, 2004 (working paper - primeira versão sobre a história da população portuguesa nos séculos XVI e XVII - investigação realizada no âmbito do projecto POCI/DEM/57987/2004 "História da População Portuguesa: das grandes permanências à conquista da modernidade").

${ }^{7}$ Manuel Severim de Faria, Notícias de Portugal, Lisboa, A. I. Fonseca, 1740, p. 5;10-11. 
compare-se a população de origem portuguesa residente em Cabo Verde, em 1572, que rondaria os 12.600 indivíduos; 15.708 em 1582, atingindo 30.397 almas nos princípios dos anos $1630 .{ }^{8}$ Portanto, esses elementos contribuem para realçar um processo migratório da população portuguesa para o Brasil em nível bastante moderado ao longo do século XVII.

Já o principal fator determinante da população de origem africana no Brasil era o volume de escravos importados anualmente. Essa importação, por sua vez, era determinada pelo vigor da economia do açúcar de modo particular. As cifras disponíveis de escravos desembarcados ao longo do século XVIII mostram uma fase de alta entre meados da década de 1630 e meados da década de 1640, seguida de retração até a década de 1680, quando se observa novamente crescimento das importações de africanos (Gráfico 1). A partir de 1697, contudo, nota-se claramente uma aceleração na tendência de alta, agora explicada pela entrada em cena da produção aurífera.

\section{Conclusão inevitável: as cifras de \\ Contreiras Rodrigues para o século XVII não são minimamente aceitáveis}

Mais difícil de medir é a incorporação das populações indígenas à sociedade colonial. Obviamente, não se trata aqui de considerar a presumível população indígena total à época da chegada dos portugueses, cujas estimativas variam de um a cinco milhões de pessoas. ${ }^{9}$ A questão central é encontrar bases que permitam estabelecer algum número minimamente consistente. A inclusão da população de origem indígena na sociedade colonial esteve condicionada, em grande medida, a três variáveis: os surtos de epidemias a que estava submetida periodicamente; as guerras de extermínio, que atingem o paroxismo ao longo da segunda metade do século XVII na Guerra dos Bárbaros; e a escravização levada e efeito principalmente pelos bandeirantes. ${ }^{10}$ Esta última é a variável

\footnotetext{
${ }^{8}$ Maria Luísa Pinto; Teresa Maria Ferreira Rodrigues, Aspectos do povoamento das ilhas da Madeira e Porto Santo nos séculos XV e XVI, Atas do Terceiro Colóquio Internacional de História da Madeira, 1993, p. 403-471. ${ }^{9}$ A cifra de um milhão é atribuída por Ángel Rosenblat, La población indígena de América desde 1492 hasta la actualidad, Buenos Aires, ICE, 1945; a de 2,4 milhões, por John Hemming, Red gold: the conquest of the Brazilian indians, 1500-1760, Cambridge, Harvard University Press, 1978 (cifra, aliás, que ele próprio toma como "pure guess-work" a partir de presumidas taxas de despovoamento de 28 regiões do país); já a estimativa de 4,8 milhões deve-se a William M. Denevan, The native population of the Americas in 1492, Maddison, The University of Winsconsin Press, 1976 (números válidos para o norte e centro do Brasil, inclusive Amazônia). 0 problema deste último está em basear sua estimativa no potencial agrícola, variável inconsistente para uma população de caçadores e coletores.

10Sobre as epidemias, cf. Daniela Buono Calainho, "Jesuítas e medicina no Brasil colonial”, Tempo, vol. 10, n. 19, 2005, p. 61-75, em especial, p. 70-71; Stuart Schwartz, Segredos internos, São Paulo, Companhia das Letras, 1988, p. 51-52; 57-73. A essas calamidades acrescente-se ainda a fome, segundo John Manuel Monteiro, Negros da terra: índios e bandeirantes nas origens de São Paulo, São Paulo, Companhia das Letras, 1994, p. 157-158. Sobre a Guerra dos Bárbaros, cf. Pedro Puntoni, A Guerra dos Bárbaros: povos indígenas e a colonização do sertão nordeste do Brasil, 1650-1720, São Paulo, Hucitec, 2002. Nas palavras desse autor (p. 17), "o que vimos surgir no decorrer da Guerra dos Bárbaros foi uma nova orientação política do Império português, levada a termo pelos seus agentes coloniais com o fim de produzir o extermínio das nações indígenas do sertão norte".
} 


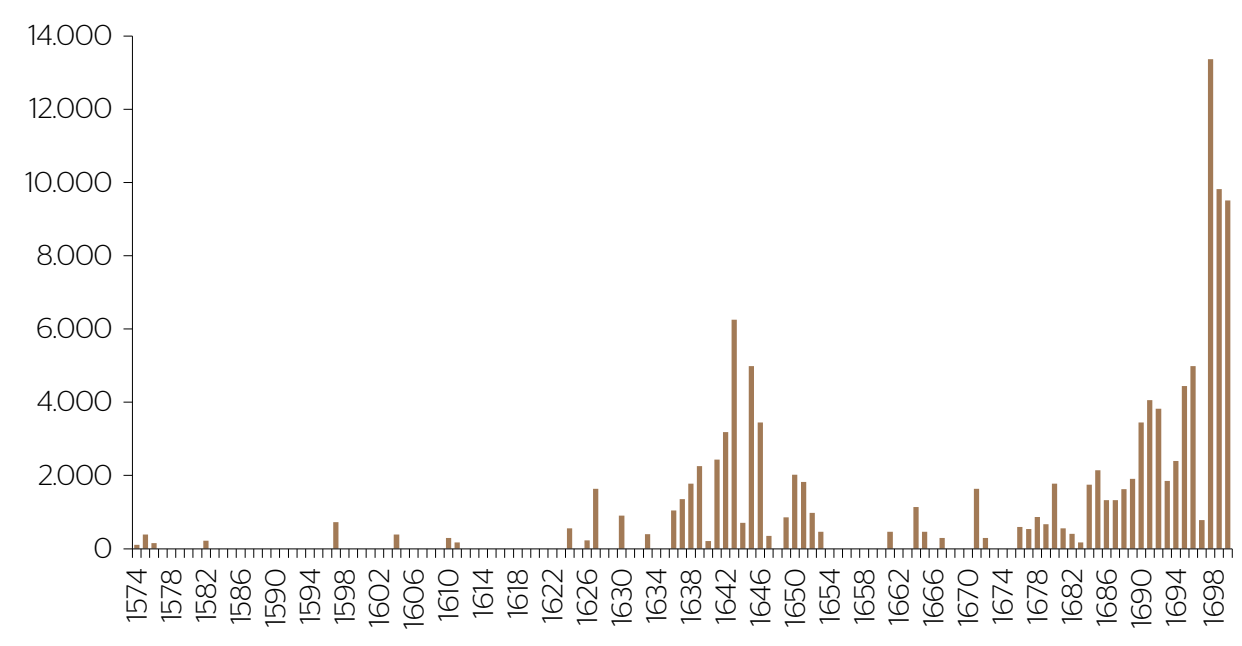

Fonte: Elaborado pelo autor, com base em D. Eltis et al., The Transatlantic Slave Trade: a database on CD-ROM, Cambridge, Cambridge University Press, 1999. Disponível em: <http://www.slavevoyages.org/>. Acesso em: 15 de março de 2014.

\section{Gráfico 1. Escravos desembarcados no Brasil, 1574-1808.}

que de fato contribui para a inclusão desse grupo no conjunto da população colonial, mas, uma vez escravizados, qual o percentual dessa participação? Na avaliação de John Monteiro, "a taxa de sobrevivência dos cativos permaneceu sempre muito baixa no período imediatamente posterior ao apresamento". ${ }^{11}$ Deve-se, por fim, considerar os vários aldeamentos indígenas empreendidos pelos jesuítas, mas, em relação aos quais, para o período que aqui interessa, pouco se pode avançar. O mesmo vale para a região norte da América portuguesa.

Em síntese, os elementos apresentados anteriormente apontam que a migração da população portuguesa para o Brasil teria ocorrido a uma taxa bastante moderada ao longo do século XVII. No que respeita à população de origem africana, o número de escravos desembarcados no período teria experimentado uma alta considerável entre as décadas de 1630 e 1640, caindo em seguida para um nível que se manteve relativamente estável até a década de 1680 , quando novamente começa a descrever uma trajetória de alta que acelera-se fortemente nos anos finais da década de 1690. Como obviamente não se trata de um movimento de migração, mas, antes de tudo, de importação de uma mercadoria indispensável à produção direta ou indiretamente voltada à exportação, os altos e baixos dos fluxos de desembarque de africanos no Brasil devem ser buscados nas conjunturas econômicas particulares. Para a população indígena, o quadro é um pouco menos seguro, em virtude de sua redução contínua.

"John Manuel Monteiro, Negros da terra: índios e bandeirantes nas origens de São Paulo, São Paulo, Companhia das Letras, 1994, p. 157. 


\section{Portanto, uma revisão das cifras requer que se tomem como ponto de par- tida os autores do último terço do século XVI: Gândavo, Anchieta, Cardim, bem como Francisco Soares (Tabela 1).}

Tabela 1. População do Brasil em fogos, 1570-1590

\begin{tabular}{|c|c|c|c|c|c|c|c|c|c|c|}
\hline \multirow{2}{*}{ Capitanias } & \multirow{2}{*}{1570} & \multicolumn{3}{|c|}{1583} & \multicolumn{3}{|c|}{1585} & \multicolumn{3}{|c|}{ ca. 1590} \\
\hline & & a & b & $\mathrm{C}$ & a & b & c & $a$ & b & c \\
\hline ama & 100 & - & - & - & 50 & - & - & 90 & 250 & - \\
\hline araíb & - & - & - & - & . & - & - & 150 & 400 & - \\
\hline ern & DO० & 1.000 & - & 2.000 & 1.110 & 10.000 & 2.000 & 2.000 & 18.000 & 2.000 \\
\hline ahia & 1.100 & 3.000 & 3.500 & 8.000 & 2.000 & 3.000 & 8.000 & 1.500 & 18.000 & 3.600 \\
\hline héus & 200 & 150 & - & - & 150 & 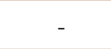 & - & 300 & 400 & 2.000 \\
\hline artc & 220 & 40 & - & - & 100 & - & - & 290 & 3.000 & 3.000 \\
\hline spíl & 180 & 150 & - & - & 15 & - & 4.500 & 400 & 700 & 9.000 \\
\hline o d & 140 & 150 & - & - & 150 & - & 3.000 & 280 & 700 & 3.000 \\
\hline ão Vicente & 500 & 330 & - & - & 300 & - & - & 600 & 800 & 6.000 \\
\hline zin & 3.440 & 4.820 & 500 & 0.000 & 4.010 & 3.00 & 7.500 & 5.610 & 42.250 & 28.600 \\
\hline
\end{tabular}

a: total de fogos (ou, mais comumente nas fontes, "vizinhos") de portugueses; b: total de escravos africanos; c: total de índios cristãos.

Fontes: para 1570: Pero de Magalhães Gândavo, Tratado da terra do Brasil, Belo Horizonte, Itatiaia, 1980, capítulos 1 a 9; 2) para 1583: Fernão Cardim, "Narrativa epistolar de uma viagem e missão jesuítica", In: Fernão Cardim, Tratados da terra e da gente do Brasil, Rio de Janeiro, J. Leite, 1925, p. 279-415: "terá a cidade [da Bahia] com seu termo passante de três mil vizinhos portugueses, oito mil índios cristãos, e três ou quatro mil escravos de Guiné"; "a vila de Nossa Senhora da Vitória [do Espírito Santo] terá mais de 150 vizinhos com seu vigário"; "a cidade [do Rio de Janeiro] tem 150 vizinhos com seu vigário e muita escravaria da terra”; a população portuguesa da capitania de São Vicente se distribuía pelas vilas de Piratininga ("120 vizinhos com sua escravaria da terra" [p. 356]; "120 vizinhos ou mais" [p. 359]); São Vicente, com 80; Santos, 80, e Itanhaém, 50; 3) para 1585: José de Anchieta (Padre), "Informação da Província do Brasil para nosso padre, 1585", In: ___. Cartas, informações, fragmentos históricos e sermões do padre José de Anchieta, S. J. (1554-1594), Rio de Janeiro, Civilização Brasileira, 1933, p. 409-447. Esse documento corresponde à tradução do manuscrito em língua espanhola e letra contemporânea do século XVI pertencente à Biblioteca de Évora, publicada por Capistrano de Abreu - José de Anchieta, Informações e fragmentos historicos do padre Joseph de Anchieta, S.J. (1584-1586) [Pref. de João Capistrano de Abreu], Rio de Janeiro, Imprensa Nacional, 1886, p. VII e nota na p. 55-56 (Cartas jesuíticas; Folha de rosto adicional: "Materiaes e achegas para a Historia e Geographia do Brasil publicadas por ordem do Ministerio da Fazenda. n. 1, julho de 1886"). Capistrano sustenta aí a autoria de Anchieta e a data - 1585, bem como discute a patente semelhança de vários trechos da Informação de Anchieta com a Narrativa epistolar de Fernão Cardim; o total da capitania de Pernambuco equivale à soma dos habitantes de Olinda ("1.000 vizinhos com sua comarca de portugueses, com seu vigário e outros clérigos seculares") e Igaraçu ("110 vizinhos de brancos com seu vigário"); sobre Salvador, anotou não ser "muito grande porque a maior parte da gente vive fora em seus engenhos e fazendas; terá em toda sua comarca quase 2.000 vizinhos portugueses, dos quais haverá 10.000 ou 12.000 pessoas e para seu serviço dos engenhos e mais fazendas [isto é, criados]; tem até 3.000 escravos da Guiné e de índios cristãos da terra cerca de 8.000 entre escravos e livres"; a população da capitania de Porto Seguro se distribuía por duas vilas: Santa Cruz, com 50 vizinhos, e Porto Seguro, com 50; Espírito Santo: 150 vizinhos; a população portuguesa da capitania de São Vicente se distribuía pelas vilas de São Vicente (50 fogos), Santos (100), Itanhaém (30 "vizinhos de brancos") e Piratininga (120 fogos); 4) para ca. 1590: Francisco Soares, Coisas notáveis do Brasil, vol. 1, Rio de Janeiro, Instituto Nacional do Livro, 1966, p. 11. Originalmente publicado em arquivo bibliográfico da Biblioteca da Universidade de Coimbra (título atual: Boletim da Biblioteca da Universidade de Coimbra), vol. 4, Coimbra, Imprensa da Universidade de Coimbra, 1904, bem como na Revista do Instituto Histórico e Geográfico Brasileiro, vol. 2, 1923, p. 367-421.

Nota: Harold Johnson dá um total de 12 mil pessoas para Pernambuco em 1585 e atribui a cada fogo o total de seis indivíduos. Harold Johnson, "The Portuguese settlement of Brazil, 1500-1580", In: Leslie Bethell, Cambridge History of Latin America, vol. 1, Cambridge, Cambridge University Press, 1984, p. 279. 
Escrevendo dois anos depois de Anchieta, Gabriel Soares de Souza apresenta cifras que, ainda que restritas a Pernambuco e Bahia, corroboram os dados anteriores. Orçou a população de Olinda em 700 vizinhos, mas destacou haver

muitos mais no seu termo, porque em cada um destes engenhos vivem vinte e trinta vizinhos, fora os que vivem nas roças afastados deles, que é muita gente; de maneira que, quando for necessário a juntar-se esta gente com armas, pôr-se-ão em campo mais de três mil homens de peleja, com os moradores, da vila de Cosmos [Igarassu], entre os quais haverá quatrocentos homens de cavalo. Esta gente pode trazer de suas fazendas quatro ou cinco mil escravos de Guiné e muitos do gentio da terra.

Do mesmo modo, para Salvador, atribuiu uma população de cerca de 800 vizinhos, mas ressaltou que

por fora dela em todos os recôncavos da Bahia, haverá mais de dois mil vizinhos, dentre os quais e os da cidade se pode ajuntar, quando cumprir, quinhentos homens de cavalo e mais de dois mil de pé, afora a gente dos navios que estão sempre no porto. ${ }^{12}$

\section{O Brasil não estava na lista dos responsáveis pela redução da população portuguesa, que, em 1640, seria igual à encontrada em 1527-1532}

Tendo em vista o maior detalhamento das cifras de Anchieta, são elas que tomo aqui como ponto de partida para a estimativa da população nos fins do século XVI, o que dá algo em torno de 60 mil habitantes em 1585. Infelizmente, são exatamente isto: ponto de partida, pois não contamos desde então com informações de igual qualidade. À volta do ano de 1590, as cifras que, "segundo... [sua] lembrança", foram apresentadas pelo padre Francisco Soares resultavam num número bem mais elevado: quase cem mil indivíduos entre portugueses (28.050), escravos (42.250) e índios (28.600). Trata-se de valor visivelmente inflacionado, a julgar pelo número tanto de fogos de portugueses como de escravos.

Do alvorecer do século XVII, há duas fontes que, em grande medida, coincidem nas cifras. Em 1611, segundo Diogo de Campos Moreno, Ilhéus contaria 250 moradores (palavra usada com o mesmo sentido de vizinhos). Sobre a Bahia, Moreno assinalou: "é este Recôncavo o mais povoado sítio de toda a costa, e nele, por suas fazendas vive a gente nobre e passam de três mil os moradores brancos". Em Sergipe, o total seria 200 e, em Pernambuco, quatro mil. Por fim, tem-se a Paraíba, que "por seus engenhos e fazendas [teria] mais de 700 moradores brancos, que com seus escravos e famílias fazem grande número”.

${ }^{12}$ Gabriel Soares de Souza, Tratado descritivo do Brasil em 1587, Rio de Janeiro, J. I. da Silva, 1879, p. 23;109. 
Sua capital, Filipéia, contaria 80 vizinhos brancos, além de oito aldeias de índios, "copiosas de gente, administradas pela doutrina dos padres franciscos e bentos".13

Outro documento, territorialmente mais abrangente, informa que, no Rio Grande do Norte, viviam "30 vizinhos... de criações de gados, mantimentos que cultivam e pescaria”, alcançando os dízimos o valor de $250 \$ 000$ réis. Na Paraíba, residiriam "100 vizinhos portugueses", e "em seu distrito... mais de 800 portugueses", distribuídos por 14 ou 15 engenhos de açúcar. Além desses, "mais de 14.000 potiguares gentios da terra" e outras nações "repartidas por suas aldeias que estão a cargo dos frades menores de São Francisco". A produção de açúcar renderia de seis a sete mil arrobas. Itamaracá era a residência de 500 moradores brancos e onde eram produzidas 2.500 arrobas de açúcar. A população de Pernambuco chegaria a "mais de 4.000 portugueses em seu distrito", rendendo os dízimos 23 mil arrobas de açúcar. Sergipe teria 50 moradores e a Bahia, três mil portugueses. A produção de açúcar renderia 14 mil arrobas. Ilhéus não teria cem moradores e Porto Seguro, apenas 40 vivendo "de farinhas de mandioca que ali lavram com alguns legumes". Do Espírito Santo, apenas informa que a produção de açúcar atingia 1.500 arrobas, a mesma produção do Rio de Janeiro, que, por seu turno, contaria com "mais de seiscentos moradores portugueses". Na última capitania, São Vicente, viveriam mais de 700 moradores portugueses, que produziam 800 arrobas de açúcar. ${ }^{14}$

Pois bem: a julgar pelos números de Diogo Moreno, em 25 anos, teria ocorrido um forte incremento populacional na Bahia (50\%), Ilhéus (66\%), Paraíba e, mais notável ainda, em Pernambuco, que quadruplicou sua população portuguesa. Esse crescimento permite inferir uma população total de no mínimo 80 mil pessoas entre portugueses, índios cristãos e escravos africanos. Exceto para Ilhéus, o período de 1585 a 1612, ano do relato de Diogo Moreno, de fato coincide com um acentuado crescimento da produção açucareira nordestina, medida tanto pelo número de engenhos (Tabela 2) como pela arrecadação dos dízimos.

\footnotetext{
${ }^{13}$ Diogo de Campos Moreno, Livro que dá razão ao Estado do Brasil [1612], Ed. crítica, com introdução e notas de Hélio Viana, Recife, Arquivo Público Estadual, 1955. O total de quatro mil moradores - isto é, fogos - em Pernambuco foi registrado no códice do Porto, pois o apógrafo do Instituto Histórico e Geográfico Brasileiro traz o dobro dessa cifra. A razão estaria, no julgamento de Hélio Viana, no fato de que o exemplar do Rio de Janeiro teria atualizado os dados entre 1625 e 1627. O mesmo vale para a capitania de Itamaracá, cujos moradores seriam mais de 500, segundo a cópia do Instituto Histórico.

${ }^{14}$ Arquivos Nacionais/Torre do Tombo, Miscelâneas Manuscritas do Convento da Graça, tomo VI F, fls. 147-158, "Província do Brasil". Existe uma cópia na Biblioteca da Ajuda (Lisboa), 51-IX-25. Artur Teodoro de Matos propõea data de ca. 1607 para esse documento. De fato, o texto menciona Francisco de Aguiar Coutinho como Capitãodonatário da capitania do Espírito Santo, que o foi a partir de 1605, e Lopo de Souza, falecido em 1610, como Capitão-donatário da capitania de São Vicente. Mas, na seção referente à Bahia, o documento refere que "aqui tem Sua Majestade um novo trato com os biscainhos que pescam baleias". Ora, a pesca das baleias foi tornada monopólio régio a partir de 1616, mas já era objeto de contrato na Bahia a partir de 1614 (Artur Teodoro de Matos, "O império colonial português no início do século XVII: elementos para um estudo comparativo das suas estruturas económicas e administrativas", Arquipélago. História, 2a série, vol. 1, n. 1, 1995). A esse respeito, cf. Angelo Alves Carrara, Receitas e despesas da Real Fazenda no Brasil - século XVII, Juiz de Fora, Editora da UFJF, 2009, p. 32-33. Portanto, o documento deve ter sido produzido em um momento pouco posterior ao texto de Diogo Moreno.
} 
Tabela 2. Número de engenhos no Brasil, 1570-1629

\begin{tabular}{lccccc} 
& 1570 & 1583 & 1589 & 1612 & 1629 \\
\hline Ilhéus & 8 & 3 & 6 & 5 & 4 \\
\hline Bahia & 18 & 36 & 50 & 50 & 80 \\
\hline Pernambuco & 23 & 66 & 70 & 90 & 150 \\
Itamaracá & 1 & 0 & 2 & 10 & 18 \\
Paraíba & 0 & 0 & 2 & 12 & 24 \\
\hline Total & 50 & 105 & 130 & 167 & 276
\end{tabular}

Fontes: Stuart Schwartz, Segredos internos, São Paulo, Companhia das Letras, 1988, p. 148; Francisco Soares (Padre), Coisas notáveis do Brasil - 1590, vol. 1, Rio de Janeiro, Instituto Nacional do Livro, 1966, p. 11 (para 1589).

A redução do número de engenhos em Ilhéus não parece oferecer grandes problemas, já que sua economia não se alicerçava na produção de açúcar, mas na produção de farinha de mandioca para abastecimento do Recôncavo, como o demonstrou Marcelo Dias. ${ }^{15}$ Assim, o crescimento demográfico seria um contundente reflexo da expansão da lavoura de cana e da produção econômica diretamente vinculada à produção de açúcar. Entre os dados de 1583, mais próximos dos de Anchieta, e os de 1612, o crescimento do número de engenhos teria sido de $40 \%$ na Bahia e $73 \%$ em Pernambuco. Itamaracá e Paraíba, por sua vez, assistem a um crescimento vertiginoso. Esse movimento fortemente ascendente mantém-se até, pelo menos, às vésperas da invasão holandesa de Pernambuco.

Quanto ao montante total arrecadado com dízimos, observa-se uma forte alta entre 1608 e 1621, o que constitui outro elemento de prova do aumento acentuado da população no período: em 1608, os dízimos da Bahia chegaram a 15:200\$000 réis e os de Pernambuco, a 25:700\$000 réis; em 1621, os dízimos da Bahia já haviam alcançado a cifra de 67:100\$000 réis, isto é, mais do que o quádruplo do valor de 13 anos antes. Mas a alta acentuada da arrecadação dos dízimos - leia-se produção açucareira — entre 1608 e 1621 foi interrompida por uma forte crise em 1621-1622, cuja recuperação levou 20 anos. ${ }^{16}$

Se, no período de alta da produção açucareira, tinha ocorrido um aumento demográfico significativo, esse avanço não chamou a atenção de Frei Vicente Salvador, sendo que, para a povoação do Recife, por volta de 1627, deu "200 vizinhos". ${ }^{7}$

Para a segunda metade até os fins do século XVII, contamos com informações esparsas, mas, de todo modo, valiosas na ausência de outras de melhor qualidade. Nos meados do século XVII, o Padre Antônio Vieira estimava a população escrava no Brasil em 35 mil indivíduos, distribuída por um total de 200 engenhos, dos quais 170 eram "engenhos do Rio de Janeiro, ou engenhocas,

\footnotetext{
${ }^{15}$ Marcelo Henrique Dias, Economia, sociedade e paisagens da capitania e comarca de Ilhéus no período colonial, Tese de doutorado, Universidade Federal Fluminense, Niterói, 2007.

${ }^{16}$ Angelo Alves Carrara, Receitas e despesas da Real Fazenda no Brasil - século XVII, Juiz de Fora, Editora da UFJF, 2009, p. 80-81; 125.

17Vicente do Salvador (Frei), História do Brasil, Rio de Janeiro, Irmãos Weiszflog, 1918, p. 106.
} 
como lá lhes chamam, três dos quais não igualam na fábrica nem no rendimento um engenho pical".18 Em relação aos números de 1585, a população escrava teria triplicado.

A partir de 1656-1657,

os dízimos experimentavam uma tendência regular de alta, com os solavancos naturais determinados pelas colheitas melhores ou piores. Mas o fato inegável é a tendência constante e persistente de crescimento. Esta tendência foi abruptamente rompida em 1687, não por um movimento dos preços, mas por uma epidemia que durante anos desestruturou a produção. ${ }^{19}$

Mas não exageremos essa tendência de longo prazo: a segunda metade do século XVII é de estagnação do ponto de vista econômico e fiscal. O valor dos dízimos em 1655-1656 (mais de 46 contos de réis) só foi superado em 16951696, quando atingem 60 contos. $^{20}$

O período posterior à invasão holandesa deve ter assistido a um despovoamento das capitanias do norte de colonos portugueses que se dirigiram para a Bahia ou o Rio de Janeiro. ${ }^{21}$ A Restauração Pernambucana certamente deve ter, de imediato, provocado uma reacomodação da população, com fluxo migratório negativo para a Bahia e partes do sul e positivo para as capitanias do norte, mas que pouco haviam de influir no total do Brasil.

Assim, um século de guerras (em 1624 a 1625, invasão e ocupação de Salvador pelos holandeses; de 1630 a 1654, invasão e ocupação holandesa das capitanias do norte; a partir de 1651, a guerra dos bárbaros; em 1680, fundação da Colônia do Sacramento), de crise na economia açucareira e, para os fins do Seiscentos, um surto de cólera atuaram como fatores fortemente limitadores do aumento demográfico.

No último quartel do século XVII, dispomos, para a capitania do Rio de Janeiro, das declarações das testemunhas arroladas no processo instaurado pela Santa Sé para a elevação à categoria de bispado. ${ }^{22}$ Foram testemunhas Rodrigo do Espírito Santo, presbítero da ordem de São Bento e procurador geral de Portugal e Brasil na Cúria Romana; o padre jesuíta Antônio

\footnotetext{
${ }^{18}$ Antônio Vieira (Padre), "Parecer do padre Antônio Vieira sobre se restaurar Pernambuco e se comprar aos holandeses; Lisboa, 14 de março de 1647", In: 1856, p. 159-176.

${ }^{19}$ Angelo Alves Carrara, Receitas e despesas da Real Fazenda no Brasil - século XVII, Juiz de Fora, Editora da UFJF, 2009, p. 117.

${ }^{21}$ De acordo com Evaldo Cabral de Mello (Olinda restaurada: guerra e açúcar no Nordeste, 1630-1654, 2. ed., Rio de Janeiro, Topbooks, 1998 [1975], p. 389-90), “no Rio de Janeiro, gente do Nordeste também se estabeleceu com lavoura e engenho de açúcar [...] A nova prosperidade por que passava o Rio de Janeiro já não se devia ao comércio com o Rio da Prata, que se reduzirá a partir de 1640, mas, conforme pretendiase na Bahia, aos emigrados que haviam construído engenhos à beira-mar e ao longo dos rios". Segundo esse autor, o Rio de Janeiro oferecia inclusive maiores vantagens que a Bahia, a saber, terra mais barata e relativamente poupada dos prejuízos que as guerras holandesas trouxeram ao comércio e à navegação do açúcar brasileiro.

${ }^{22}$ Archivum Secretum Vaticanum, Archivum Consistorialis, Acta Congregationis Consistorialis, vol. 1, 13 de março de 1674, fls. 89-141. Trata-se de um conjunto de documentos, em sua maioria em latim e em italiano, composto por memorial, as inquirições e respostas das testemunhas, o processo e cartas do núncio de Lisboa.
} 
Gonçalves; o também jesuíta Antônio Vieira e o abade Martinho Mesquita. A inquirição e as respectivas respostas foram aprovadas entre setembro e outubro de 1673. No entanto, o padre Antônio Vieira declarou ter na época 64 anos. Como nasceu em fevereiro de 1608, a inquirição deve ter ocorrido de fato em $1672 .^{23}$

Do total de 23 perguntas constantes do interrogatório, têm especial interesse para o presente estudo as que se referem precisamente ao número de fogos e almas das diferentes vilas e aldeias que seriam submetidas à jurisdição do novo bispado.

Das quatro testemunhas citadas anteriormente, apenas Rodrigo do Espírito Santo e o Padre Vieira forneceram informações mais precisas, mas as do primeiro parecem ser mais consistentes. Já nas respostas tanto do padre Antônio Gonçalves como do abade Martinho Mesquita, é comum a afirmação de não saber ou apenas acreditar nisto ou naquilo. ${ }^{24}$

$$
\begin{aligned}
& \text { O período posterior à invasão holandesa } \\
& \text { deve ter assistido a um despovoamento das } \\
& \text { capitanias do norte de colonos portugueses que } \\
& \text { se dirigiram para a Bahia ou o Rio de Janeiro }
\end{aligned}
$$

Na avaliação de Rodrigo do Espírito Santo, haveria de três a quatro mil almas em três paróquias: São Sebastião (matriz), Nossa Senhora da Candelária e São José. ${ }^{25}$ Contaria com um "clero numeroso, tanto secular quanto regular e serão de 250 a 300 mais ou menos", além de "muitos nobres titulares, capitães e gente di gran posto, doutores e mestres e outras pessoas que tornam o lugar conspícuo e vivem de rendimentos próprios e da própria fazenda" (grifo do autor). Além da cidade de São Sebastião, assinala que Cabo Frio, "atualmente destruída por ter sido ocupada pelos holandeses e por eles espoliada", tinha duas igrejas e pouco mais de cem almas. Outros lugares contariam com o governo de um capitão (daí a testemunha falar em "capitanias"), como Porto Seguro, Espírito Santo, Ilha Grande, Ilha de São Sebastião, São Vicente, Parnaguá

\footnotetext{
${ }^{23}$ Rodrigo do Espírito Santo atuou mais tarde como comissário do Santo Ofício na Bahia. A esse respeito, cf. Grayce Mayre Bonfim Souza, Para remédio das almas: comissários, qualificadores e notários da Inquisição portuguesa na Bahia (1692-1804), Tese de doutorado, Universidade Federal da Bahia, Salvador, 2009, p. 70; 175-176; 186-187.

${ }^{24}$ No original: "nescio precise sed credo"; é muito representativa a afirmação de Antônio Gonçalves de que nunca havia entrado na igreja matriz da cidade do Rio de Janeiro ("nunquam ingressus fuit hanc ecclesiam"; fl. 95r). Sobre a falta de números a apresentar, "nescit precise numerum animarum"; e sobre Cabo Frio, "non intrasse civitatem de Cabo Frio". O mesmo vale para o testemunho do Abade Mesquita, com ainda maior impossibilidade de apresentar dados precisos.

${ }^{25}$ Números aliás superiores aos apresentados por Antônio Gonçalves, para quem o total de habitantes estaria em torno de dois mil ("duo millia foculariorum”, Archivum Secretum Vaticanum, Archivum Consistorialis, Acta Congregationis Consistorialis, vol. 1, 13 de março de 1674, fl. 95r).
} 
e Vila da Conceição, "muito povoados”. Em São Paulo, haveria 1.500 cristãos brancos e mais de dez mil escravos. Santos contaria com mil cristãos brancos e entre três e quatro mil escravos. Nos outros lugares, a população era menor, e o dizia "por haver estado ali".

Já Antônio Vieira ofereceu cifras mais elevadas que as de Rodrigo do Espírito Santo para a cidade do Rio de Janeiro: de quatro a cinco mil almas de portugueses, além de 20 mil escravos africanos e indígenas, buscando corroborar sua afirmação por ter estado "naquela região por mais de vinte anos". Ressaltava que, embora "não tenha ido à mesma cidade de São Sebastião [do Rio de Janeiro]", contava com os relatos dos padres do Colégio jesuítico ali existente, além dos de outros portugueses. ${ }^{26}$ Também declarou que o número de eclesiásticos ultrapassava 200. Das demais colônias de portugueses compreendidas na futura jurisdição do bispado, elencou Porto Seguro, Espírito Santo, Cabo Frio, Ilha Grande, São Paulo, São Vicente, Santos, Cananéia e outras menores até o Rio da Prata, todas com párocos e vigários. São Paulo e Espírito Santo teriam outros mosteiros de religiosos e de 13 a 14 aldeias de índios com suas igrejas, "todos cristãos, assim como todos os servos dos portugueses, fossem eles índios ou africanos". ${ }^{27}$ Até aqui, o testemunho de Vieira não parece apresentar divergências importantes com o anterior. É no número total para toda a capitania que aparece uma profunda discrepância. Vieira apresenta a cifra de "mais de 200.000 almas". ${ }^{28} \mathrm{O}$ fato de Vieira não ter de fato colhido informações in loco, estar ausente do Brasil há mais de uma década e dispor de informações de segunda mão, ainda que de membros de sua mesma congregação, torna os dados por ele apresentados menos consistentes que os de Frei Rodrigo. No caso particular do número de habitantes da cidade do Rio de Janeiro, há uma variação considerável: um número mais baixo de duas mil almas proposto por Antônio Gonçalves, de três a quatro mil por Frei Rodrigo e um mais elevado, de quatro a cinco mil almas, pelo Padre Vieira. A estes acrescente-se a cifra que o núncio apostólico e arcebispo de Calcedônia, Marcelo Durazzo, apresentou em carta escrita em Lisboa datada de 2 de maio de 1673 - três mil almas. ${ }^{29}$

Pelas informações mais detalhadas e fundamentadas, são tomadas aqui as cifras referidas por Rodrigo do Espírito Santo como mais consistentes, isto é:

\footnotetext{
${ }^{26}$ Archivum Secretum Vaticanum, Archivum Consistorialis, Acta Congregationis Consistorialis, vol. 1, 13 de março de 1674, fl. 96v: "quatuor vel quinque millia animarum ex Lusitanis verumtamen, ex ipsis Brasilianis et Angolanis qui sunt Etiopes [sic] et servi christiani tamen amplecti viginti circa millia animarum, et h[a]ec scire quia fui in illa regione viginti et amplius annos, et quamvis non fuerim in ipsa civitate S. Sebastiani, nihil h[a] ec audivi publice, et palam ex continuo co[m] mercio cum patribus societatis ex quo in ibi adest Collegium et cum aliis Lusitanis et est publicum et notorium".

${ }^{27}$ Ibidem, fl. 96v: "qui omnes sunt christiani sicut etiam omnes servi Lusitanorum tam ex Brasiliensibus quam ex Angolanis".

28/bidem, fl. 97r: "magnitudo totus status iuxta oram maritimam extenditur cir[cite]r per tria millia milliarum et ultra, versus mediterraneum verum nullus habet limites [...] numerus autem omnium Christianorum excedit ducenta millia".

29/bidem, fls. 89-141; 131r
} 
a) para a cidade do Rio de Janeiro, de três a quatro mil habitantes; apesar de, em seu testemunho, não oferecer uma cifra para o número de escravos, pode-se aqui atalhar essa falta com o valor dado por Vieira, de 20 mil escravos. Com isso, chegaríamos a um total de 23 a 24 mil pessoas para o Rio de Janeiro;

b) São Paulo, com pouco menos de 12 mil (1.500 brancos e o restante, escravos índios e africanos); e

c) Santos, com uns cinco mil habitantes (entre mil brancos e os demais, escravos).

Ao todo, poder-se-ia pensar num mínimo de 40 mil e um máximo de 50 mil habitantes para toda a extensa faixa do Espírito Santo a Paranaguá. O número de 200 mil oferecido por Vieira parece corresponder mais a uma perspectiva com a possível cristianização dos índios da bacia do Rio Uruguai.

Essas cifras adquirem maior consistência se considerarmos os números detalhados de cada uma das freguesias do bispado do Rio de Janeiro constantes de uma visita pastoral em 1687 (Tabela 3). Os números parecem abranger a população de origem portuguesa, africana e indígena. Isso fica muito claro no caso da freguesia de São Gonçalo, à qual é atribuído o total de 250 fogos. Se aplicarmos a regra de seis pessoas por domicílio, a freguesia teria 1.500 indivíduos, exatamente o total apresentado no documento, que discrimina 800 pessoas brancas de comunhão e 700 escravos; o mesmo vale para Nossa Senhora da Pena de Porto Seguro, cujos 141 domicílios resultariam em 846 indivíduos. O total apresentado, contudo, 745, corresponde a 495 pessoas brancas e 250 escravos. Todavia, estudos ulteriores devem esclarecer as fortes disparidades na relação entre o número de pessoas de comunhão e o número de fogos verificadas nas freguesias de São Francisco do Sul e Jacareí, de um lado, e Cotia e Iguape, de outro.

Para se considerar a população total (e não apenas as pessoas de comunhão), o documento informa que, na freguesia da Candelária, com 600 domicílios, havia 3.500 almas, das quais 2.800 eram de comunhão (isto é, $80 \%$ do total de residentes na freguesia); em São João da Barra de Paraíba, os 22 casais brancos correspondiam a 200 almas das quais 150 eram de comunhão, ou seja, 75\% do total de residentes. Se, de fato, essa proporção tiver validade, o total da população da área compreendida entre Porto Seguro e São Francisco do Sul no final da década de 1680 estaria entre 50.000 e 53.000 indivíduos. $^{30}$

Para o Maranhão, o mesmo documento contém apenas a súmula dos testemunhos, que se limitaram a apresentar São Luís como "muito numerosa de habitantes", além de alguns outros lugares "povoadíssimo[s de gentios]”.31

No início da década de 1680, o desembargador Sebastião Cardoso de Sampaio assinalou que o Estado do Brasil se achava então "tão aumentado, que a cidade

\footnotetext{
30 Victor Oliveira chegou ao total 18.578 pessoas para todas as freguesias da capitania do Rio de Janeiro, menos as de Angra dos Reis e Parati (Victor Luiz Álvares Oliveira, "Filhos naturais e elites das senzalas: compadrios e hierarquias sociais em uma freguesia rural do Rio de Janeiro (1691-1721)", Revista 7 Mares, n. 4. 2014, p. 59-76). Esse total inclui as 3.500 almas da freguesia da Candelária e não as 2.800 de comunhão.

${ }^{31}$ Archivum Secretum Vaticanum, Archivum Consistorialis, Acta Congregationis Consistorialis, vol. 1, 13 de março de 1674, fls. 89-141; 117r-123r.
} 
Tabela 3. População das freguesias e capelas curadas do bispado do Rio de Janeiro por freguesia, 1687

\begin{tabular}{|c|c|c|c|}
\hline & $\mathrm{F}$ & PC & $\mathrm{PC} / \mathrm{F}$ \\
\hline \multicolumn{4}{|l|}{ Rio de Janeiro } \\
\hline Sé & 650 & 3.500 & 5,38 \\
\hline Candelária & 600 & 2.800 & 4,67 \\
\hline Santo Antônio de Macacu [ou do Caceribu] & 167 & 1.037 & 6,21 \\
\hline Santíssima Trindade & 60 & 500 & 8,33 \\
\hline Nossa Senhora do Desterro de Itambi & 95 & 693 & 7,29 \\
\hline São João de Itaboraí & 91 & 382 & 4,20 \\
\hline Nossa Senhora da Piedade de Magé & 148 & 547 & 3,70 \\
\hline São Nicolau de Suruí & - & 400 & - \\
\hline Nossa Senhora da Guia de Pacobaíba & 71 & 448 & 6,31 \\
\hline Santo Antônio [de Iguaçu] & 100 & 212 & 2,12 \\
\hline Nossa Senhora da Piedade de Inhomirim & 60 & 300 & 5,00 \\
\hline Nossa Senhora da Apresentação de Irajá & 200 & 1.800 & 9,00 \\
\hline São João de Meriti & - & - & - \\
\hline Nossa Senhora da Conceição de Marapicú & 65 & 396 & 6,09 \\
\hline Nossa Senhora da Ajuda de Guapimirim & 49 & 330 & 6,73 \\
\hline São Tiago de Inhaúma & 75 & 550 & 7,33 \\
\hline Nossa Senhora do Loreto de Jacarepaguá & 186 & 400 & 2,15 \\
\hline Nossa Senhora do Desterro de Campo Grande & 70 & 313 & 4,47 \\
\hline Santo Antônio de Inhoaíba & 30 & 150 & 5,00 \\
\hline São Gonçalo & 250 & - & - \\
\hline São João de Icaraí & 134 & 1.420 & 10,60 \\
\hline São Sebastião de Itaipu & 20 & 50 & 2,50 \\
\hline Nossa Senhora do Bonsucesso de Piratininga & 18 & 170 & 9,44 \\
\hline Nossa Senhora da Assunção de Cabo Frio & 81 & 459 & 5,67 \\
\hline São Salvador dos Campos & 150 & 800 & 5,33 \\
\hline São João da Barra de Paraíba & 22 & 150 & 6,82 \\
\hline Nossa Senhora de Nazaré de Saquarema & 60 & 150 & 2,50 \\
\hline Nossa Senhora do Amparo de Maricá & 70 & 180 & 2,57 \\
\hline Vila de Angra dos Reis da IIha Grande & 152 & 606 & 3,99 \\
\hline Vila de Parati & 65 & 240 & 3,69 \\
\hline Subtotal & 3.739 & 18.983 & 5,07 \\
\hline \multicolumn{4}{|l|}{ Espírito Santo } \\
\hline Nossa Senhora da Vitória do Espírito Santo & 288 & 2.026 & 7,03 \\
\hline Vila Velha do Espírito Santo & 60 & 200 & 3,33 \\
\hline Nossa Senhora da Conceição de Guarapari & 34 & 270 & 7,94 \\
\hline Aldeia de índios em Guarapari & 200 & 400 & 2,00 \\
\hline Subtotal & 582 & 2.896 & 4,97 \\
\hline \multicolumn{4}{|l|}{ Porto Seguro } \\
\hline Nossa Senhora da Pena de Porto Seguro & 141 & 745 & 5,28 \\
\hline Santa Cruz do Porto Seguro & 47 & 285 & 6,06 \\
\hline Aldeia de índios em Santa Cruz do Porto Seguro & 32 & 77 & 2,41 \\
\hline Santo Antônio de Caravelas & 60 & 120 & 2,00 \\
\hline Subtotal & 280 & 1.227 & 4,38 \\
\hline
\end{tabular}


Tabela 3. Continuação

\begin{tabular}{|c|c|c|c|}
\hline & $\mathrm{F}$ & PC & $\mathrm{PC} / \mathrm{F}$ \\
\hline \multicolumn{4}{|l|}{ São Paulo } \\
\hline Vila de São Paulo & - & 1.520 & - \\
\hline Santo Amaro & 118 & 740 & 6,27 \\
\hline Nossa Senhora do Monserrate [de Cotia] & 72 & 100 & 1,39 \\
\hline São João [de Atibaia] & 147 & 457 & 3,11 \\
\hline Nossa Senhora do Desterro [de Mairiporã] & 43 & 200 & 4,65 \\
\hline Nossa Senhora da Conceição [de Araçariguama] & 65 & 430 & 6,62 \\
\hline Vila de Jundiaí & 69 & 309 & 4,48 \\
\hline Vila de Jacareí & 144 & 4.010 & 27,85 \\
\hline Vila de Taubaté & 353 & 1.400 & 3,97 \\
\hline Vila de Santo Antônio de Guaratinguetá & 61 & 250 & 4,10 \\
\hline Vila de Pindamonhangaba & 56 & 152 & 2,71 \\
\hline Vila de Mogi & 296 & 692 & 2,34 \\
\hline Vila de Itu & 300 & 2.000 & 6,67 \\
\hline Vila de Sorocaba & 75 & 300 & 4,00 \\
\hline Vila de Parnaíba & 300 & 900 & 3,00 \\
\hline Vila de Ubatuba & 67 & 242 & 3,61 \\
\hline Vila de São Sebastião & 125 & 500 & 4,00 \\
\hline Vila de São Vicente & 70 & 400 & 5,71 \\
\hline Vila de Santos & 170 & 500 & 2,94 \\
\hline Vila da Conceição & 70 & 500 & 7,14 \\
\hline Vila de Iguape & 67 & 96 & 1,43 \\
\hline Vila de Cananeia & 57 & 290 & 5,09 \\
\hline Subtotal & 2.725 & 15.988 & 5,87 \\
\hline \multicolumn{4}{|l|}{ Santa Catarina e Paraná } \\
\hline Vila do Rio de São Francisco [do Sul] & 17 & 370 & 21,76 \\
\hline Vila de Paranaguá & 168 & 470 & 2,80 \\
\hline Curitiba & 37 & 150 & 4,05 \\
\hline Subtotal & 222 & 990 & 4,45 \\
\hline Total & 7.548 & 39.922 & 5,29 \\
\hline
\end{tabular}

Fonte: Arquivo da Cúria Metropolitana do Rio de Janeiro/Série de Visita Pastoral/ Notícias do Bispado do Rio de Janeiro no ano de 1687 [Visitas Pastorais - VP-38].

F: fogos; PC: pessoas de comunhão; PC/F: relação entre o número de pessoas de comunhão e o número de fogos. Notas: 1) esse documento acha-se interditado em virtude da extrema fragilidade do suporte, pelo que se recorreu à transcrição disponível no Arquivo da Cúria Metropolitana do Rio de Janeiro; 2) o documento não apresenta o número de fogos e pessoas de comunhão da freguesia de São João de Meriti; 3) o total de fogos de São Nicolau de Suruí, no atual município de Magé, está corroído no manuscrito; 4) para São Gonçalo, o documento discrimina 800 pessoas brancas de comunhão e 700 escravos; 5) em Nossa Senhora da Vitória do Espírito Santo, o total de 2.026 corresponde a brancos e negros; 6) em Nossa Senhora da Pena de Porto Seguro, o total corresponde a 495 pessoas brancas e 250 escravos; 7) para a aldeia de índios em Santa Cruz do Porto Seguro, o documento registra 32 fogos e 77 "índios da terra"; 8) em lugar de "fogos", o documento refere-se a "casais" em São João da Barra da Paraíba, Santo Antônio de Caravelas e Guarapari. 
da Bahia passa de 3.000 vizinhos, e no recôncavo e sertão com inumerável gente".32 Isso fazia de Salvador uma cidade que teria entre 12 e 15 mil pessoas.

Na última década do século XVII, contudo, contamos com estimativas bem mais sólidas: o resultado de duas visitas pastorais na diocese de Olinda em 1693 e 1701 (Tabela 4). No primeiro caso, o total de habitantes situar-se-ia entre os 53 e os 66 mil; no segundo, entre os 55 e os 68 mil. Em uma década, a população sob jurisdição do bispado de Olinda teria, portanto, experimentado um crescimento de cerca de $3 \%$.

Se para o século XVI, o número de habitantes
do Brasil proposto por Contreiras Rodrigues não
se afasta de modo importante dos autores que
constituem a referência necessária, para o
século XVII, o quadro altera-se fortemente

Ademais, levando-se em conta o quadro econômico da segunda metade do século XVIII, caracterizado por relativa estabilidade na produção dos principais gêneros agrícolas - os valores dos contratos dos dízimos deflacionados mantêm-se rigorosamente nos mesmos níveis da década de 1650 - , as cifras disponíveis para o Rio de Janeiro, em 1673, e a Bahia, em 1681, não devem ter sofrido variação de monta. ${ }^{33}$ Talvez já não valesse mais a proporção assinalada por Anchieta, segundo quem a população da capitania da Bahia corresponderia a duas vezes e meia a população de Salvador, o que daria, a partir dos números vistos anteriormente, um total, em 1680, de 7.500 fogos de portugueses, ou 45 mil pessoas (seis pessoas por fogo). Essa cifra é de fato muito baixa quando comparada com a de Pernambuco, ainda que de dez anos depois. Mas não se deve perder de vista o que também se destacou anteriormente com relação aos fatores limitadores do aumento demográfico na segunda metade do século XVII. Ora, se pudesse ser estabelecida alguma relação entre a produção agrícola total das três capitanias (Bahia, Pernambuco e Rio de Janeiro) entre 1670 e 1700, medida pelo valor dos dízimos, ainda que estes expressassem em sua quase totalidade a produção destinada à exportação, então as cifras da Bahia em 1680, as de Pernambuco em 1693 e 1701 e as do Rio de Janeiro em 1673 produziriam mais concordância do que discordância. Bahia e Pernambuco responderiam juntas por três quartos, pelo menos, da população total do Brasil, ficando a capitania do Rio de Janeiro com o quarto faltante. Para os anos finais do século XVII, atribuindo-se um valor máximo tanto para Pernambuco quanto para a Bahia, da ordem de 70 mil pessoas, e de 40 a 50 mil pessoas para toda a

\footnotetext{
${ }^{32}$ Arquivo Histórico Ultramarino (AHU)/BA, Papel que fez o desembargador Sebastião Cardoso de Sampaio, [no] tocante às coisas da Fazenda e Justiça e governo do Brasil, Lisboa, 16 de janeiro de 1681 (Série Luísa da Fonseca, cx. 24, doc. 2972).

${ }^{33} \mathrm{~A}$ esse respeito, $\mathrm{cf}$. a análise com base na arrecadação total dos dízimos em Angelo Alves Carrara, Receitas e despesas da Real Fazenda no Brasil - século XVII, Juiz de Fora, Editora da UFJF, 2009, p. 80-81; 85.
} 
Tabela 4. Número de fogos do bispado de Pernambuco, 1693-1701

\begin{tabular}{|c|c|c|}
\hline & 1693 & 1701 \\
\hline \multicolumn{3}{|c|}{$\begin{array}{l}\text { Faixa I - da Paraiba ao norte de Alagoas: } 300 \text { km de costa entre Mamanguape } \\
\text { e Camaragibe }\end{array}$} \\
\hline Mamanguape & 130 & 90 \\
\hline Duas pequenas aldeias de índios & 70 & \\
\hline Paraíba & 1.600 & 1.650 \\
\hline Taquara & 150 & 200 \\
\hline Desterro (atual Itambé) & 72 & - \\
\hline Goiana & 600 & 600 \\
\hline Tejucopapo & 208 & 180 \\
\hline Itamaracá & 160 & 280 \\
\hline Igarassu & 400 & 600 \\
\hline Tracunhaém & 100 & 260 \\
\hline São Lourenço da Mata & 850 & 450 \\
\hline Aldeia de Limoeiro (a 85 km do Recife) & 20 & - \\
\hline Aldeia de Araribá (a 200 km do Recife) & 50 & - \\
\hline Nossa Senhora da Luz da Mata & - & 320 \\
\hline Maranguape & 70 & 100 \\
\hline Olinda & - & 660 \\
\hline São Pedro Mártir & - & 200 \\
\hline Recife & 2.000 & 2.450 \\
\hline Várzea & 600 & 260 \\
\hline Santo Antônio da Mata (a 50 km do Recife) & 90 & 150 \\
\hline Muribeca & 400 & 400 \\
\hline Jaboatão & 314 & 350 \\
\hline Cabo de Santo Agostinho & 650 & 700 \\
\hline Ipojuca & 300 & 300 \\
\hline Aldeia de índios & 840 & - \\
\hline Serinhaém & 600 & 400 \\
\hline Una & 200 & 200 \\
\hline Aldeia de índios & 80 & - \\
\hline São Bento & - & 120 \\
\hline Porto Calvo & 370 & 255 \\
\hline Camaragibe & 230 & 310 \\
\hline Subtotal & 11.154 & 11.485 \\
\hline \multicolumn{3}{|c|}{ Faixa II - Alagoas: 150 km entre as Alagoas e Penedo } \\
\hline Lagoa do Norte & 212 & 200 \\
\hline Lagoa do Sul & 307 & 540 \\
\hline São Miguel & 150 & 180 \\
\hline Rio de São Francisco/Penedo & 500 & 300 \\
\hline Subtotal & 1.169 & 1.220 \\
\hline
\end{tabular}


Tabela 4. Continuação

\begin{tabular}{lcc} 
& 1693 & 1701 \\
\hline Faixa III - Rio Grande do Norte & - & 120 \\
Goianinha & 300 & 400 \\
Rio Grande do Norte & 200 & - \\
$\quad$ Duas aldeias & 50 & - \\
$\quad$ Duas aldeias & 550 & 520 \\
Subtotal & & \\
Sertão & 280 & 115 \\
Rodelas & - & 80 \\
Ceará & - & \\
Rio Grande do Sul & - & 160 \\
Rio de Piauí & 280 & - \\
Lugar entre Piancó e Piranhas & 13.153 & 1355 \\
Subtotal & & 13.580 \\
\hline Total
\end{tabular}

Fonte: Archivium Secretum Vaticanum/Congregazione del Concilio/Relationes diocesium 596 - fólios não numerados. Os documentos trazem as datas de 11 de julho de 1693 e 7 de maio de 1701, respectivamente; este último tem também uma versão em italiano intitulada Visita che monsignore D. F. Francesco de Lima, vescovo Olinden[se] Pernambuccano ne/[lo] stato del Brasile in Indiis Occidentalibus fà ad sacra limina apostolorum, e relatione que del d[ett]o suo vescovato da a nostro signore per l'avvocato Manuele Banha Quaresma, chierico e beneficiato eborense suo procuratore.

Notas: 1) o número de fogos apresentado em 1693 para o Recife (dez mil) constitui erro evidente, devendo referirse ao número de habitantes e, nesse caso, a um total de dois mil fogos (ao invés de "dieci milla fuochi", "due milla fuochi"); ademais, não apresenta cifras para as freguesias da Sé de Olinda e de São Pedro Mártir. Esse erro é igualmente destacado por Bruno Feitler, Nas malhas da consciência - Igreja e Inquisição no Brasil: Nordeste 16401750, São Paulo, Phoebus; Alameda, 2007, p. 47; 2) as freguesias mencionadas nos documentos correspondem atualmente aos seguintes lugares: 2.1) a cidade da Paraíba é hoje João Pessoa; 2.2) na freguesia de Goiana, é incluída a aldeia de índios uraitaigi, sem menção do número de fogos, que correspondente hoje ao município de Alhandra; 2.3) Taquara: atualmente distrito do município de Pitimbu (PB); 2.4) Desterro: atual município Itambé; 2.5) Tejucopapo: atualmente distrito do município de Goiana (PE); 2.6) Maranguape: atualmente bairro da cidade de Paulista (PE); 2.7) Várzea: atualmente bairro da cidade de Recife; 2.8) Nossa Senhora da Luz da Mata, atualmente distrito de Matriz da Luz, no município de São Lourenço da Mata, a 15 km do centro da cidade homônima; 2.9) Muribeca: atualmente bairro da cidade de Jaboatão dos Guararapes; 2.10) no documento de 1693, a aldeia de Araribá está grafada "Ararota"; corresponde hoje ao município de Pesqueira (PE), distante 200 km do Recife; 2.11) Una: segundo José Cezar de Menezes (Idéa da população da capitania de Pernambuco: e das suas annexas ... desada o anno de 1774 em que tomou posse do governo das mesmas capitania, Rio de Janeiro: Officinas Graphicas da Bibliotheca Nacional, 1924, p. 48-49), "a matriz de Nossa Senhora da Purificação [orago indicado em 1693] e São Gonçalo [orago indicado em 1701]... e sua povoação está situada em um monte a que chamam de São Gonçalo, vizinho ao rio de Una"; situava-se na margem esquerda do rio e integra hoje a cidade de Barreiros (PE); 2.12) Camaragibe: não confundir com o município homônimo próximo ao Recife; 2.13) "Lagoa" no documento de 1693; "Alagoa” no de 1701. Alagoa do Norte: atual Maceió; Alagoa do Sul: atual município de Marechal Floriano, ambos em Alagoas; a freguesia da Alagoa do Sul inclui uma aldeia de índios sem indicação do número de fogos; 2.14) São Miguel: atual município de São Miguel dos Campos (AL); 2.15) Rio de Piauí: paróquia de Nossa Senhora da Vitória, atual município de Oeiras (PI); 3) "Rio de São Francisco" no documento de 1693; "Penedo", no de 1701; inclui quatro aldeias de índios sem indicação do número de fogos; 4) as três últimas paróquias da tabela foram instituídas nos sertões porque "multidões de cristãos que viviam pelos dilatados sertões em muitos e grandiosos currais de gado, que são as mais rendosas fazendas, para as quais estão todos os anos indo do Reino de Portugal nas frotas multidão de homens que no Reino não têm modo de vida, e que estes passavam oito e 10 anos que não ouviam missa nem recebiam os sacramentos"; 5) Rio Grande do Sul: antiga São Francisco das Chagas do Rio Grande do Sul, atual município de Barra, na Bahia; o documento de 1701 informa: "neste sertão distante da sobredita freguesia da Conceição de Rodela 120 léguas mais para o interior do mato para a parte do poente, mandou fazer uma paróquia [...] tem 130 moradores em outros tantos currais de gado"; 6) sobre o Ceará, o documento de 1693 assinala tratar-se de "capitania e fortaleza com presídio militar distante da cidade [de Olinda] 600 milhas; assistem na [igreja] paroquial os padres da congregação de São Filipe Neri, a um dos quais incumbe cuidar das almas que são [em número de] ...", sem mencionar a cifra; o documento de 1701 ("Ceará Grande") indica ter matriz de Nossa Senhora da Assunção 80 fogos de moradores brancos e grande quantidade de índios; coincide com o atual município de Viçosa do Ceará; 7) o documento de 1701 menciona o "lugar entre Pinhanco [atual Piancó] e Piranhas", "distante da matriz da Paraíba para o sertão 150 léguas", o que dá quase 1.000 km. Ocorre que a distância de São José de Piranhas e Piancó a João Pessoa não ultrapassa os 500 km; 8) sobre o Rio Grande do Norte, o documento de 1701 informa: "matos desertos habitados de alguns moradores brancos que vivem de criar gados e de inumeráveis gentios, alguns domésticos em missões e a maior parte deles bárbaros que andam em contínuas guerras com os brancos". 
área compreendida pelo bispado do Rio de Janeiro, alcançaríamos uma cifra em torno de, e de modo algum, muito superior a 200 mil indivíduos.

Com relação ao Estado do Maranhão e Grão-Pará, os dados recolhidos e sistematizados por Rafael Chambouleyron, num conjunto bem mais variado de fontes, ainda que muito divergentes entre si, sinalizam claramente para um crescimento demográfico na segunda metade do século XVII (Tabela 5). O autor igualmente destacou uma concentração de envio de africanos nas décadas finais do século XVII. ${ }^{34}$ Se, na tabela que sintetiza os dados por ele recolhidos, aplicar-se o princípio de que "vizinho", "morador" ou "casal" corresponde a

Tabela 5. População do Estado do Maranhão e Grão-Pará, 1637-1698

\begin{tabular}{lcccccccc}
\hline & 1637 & 1660 & 1662 & 1679 & 1684 & 1685 & 1693 \\
\hline Maranhão & & & & & & & \\
São Luís & 250 & $300-500$ & $>600$ & 400 & 800 & $>1.000$ & $>600$ \\
\hline Tapuitapera & - & 100 & - & 30 & - & 400 & 300 \\
\hline Itapecuru & - & - & 100 & 300 & - & - & - \\
Pará & & & & & & & \\
Belém & 80 & 150 & 400 & - & 150 & 500 & 400 \\
\hline Gurupá & - & 30 & - & - & - & - & - \\
\hline Vigia & - & - & - & 22 & - & - & - \\
Caeté/Gurupi & - & 60 & 120 & 18 & - & - & - \\
\hline Totais & 330 & 340 & 1.220 & 770 & 950 & 1.900 & 1.300
\end{tabular}

Fontes: Rafael Chambouleyron, Portuguese colonization of the Amazon region, 1640-1706, Tese de doutorado, University of Cambridge, Cambridge, 2005, p. 65-68; Rafael Chambouleyron, "Escravos do Atlântico equatorial: tráfico negreiro para o Estado do Maranhão e Pará (século XVII e início do século XVIII)", Revista Brasileira de História, vol. 26, n. 52, 2006, p. 79-114. As fontes referidas são as seguintes: para 1637: Bento Maciel Parente, "Relação do Estado do Maranhão: 4 de fevereiro de 1637", Anais da Biblioteca Nacional, vol. 26, 1904 (1905), p. 353-359 (total de "moradores"); para a década de 1660: Notícia do Estado... Biblioteca da Ajuda, códice 50-V-37, fl. 139-139v (total de "vizinhos"; Cametá com "poucos"); para 1662: Maurício de Heriarte, "Descrição do Estado do Maranhão, Pará, Curupá e rio das Amazonas", In: Francisco Adolfo de Varnhagen, História Geral do Brasil, vol. 3, São Paulo, Melhoramentos, 1956, p. 211; 213; 217; 219; 221 (total de "moradores" em São Luís e Curupi; para Belém, "vizinhos moradores"; Gurupá com "alguns" e Cametá com "poucos moradores brancos"); para 1679. Simão e Sousa, Sobre o Maranhão e Pará e desordens dos ministros e oficiais que lá há, Biblioteca da Ajuda, Lisboa, 21 de outubro de 1679, códice 50-V-37, fls. 398-405, fl. 398 (total em "casais"); para 1684: João de Moura Colônia portuquesa que contém três tratados: no primeiro se descreve o Estado do Maranhão e forma de seu aumento, 1684, Biblioteca Nacional de Portugal, Reservados, códice 585, fl. 13v (total de "vizinhos" em São Luís e de "fogos" em Belém); para 1685: Manuel Guedes Aranha, "Papel político sobre o Estado do Maranhão" [c.1685] Revista do Instituto Histórico e Geográfico Brasileiro, 1a parte, tomo 46 (1883), p. 4; 7; 12 (o total de "vizinhos" em São Luís e de “moradores” em Belém); para 1693: João de Souza Ferreira, "América abreviada, suas notícias e de seus naturais, e em particular do Maranhão, títulos, contendas e instruções à sua conservação e aumento mu úteis" [1693], Revista do Instituto Histórico e Geográfico Brasileiro, 1a parte, tomo 57 (1894), p. 33; 37; 43 (total de "vizinhos" para São Luís e Alcântara e de "moradores" para Belém). Além destas, há duas estimativas conflitantes para a população do Estado do Maranhão em 1688: uma, de cinco ou seis mil "moradores", e outra, de dois mil "moradores": Papel sobre ... Sociedade de Geografia e Lisboa, Res. 2-B-6; e João de Sousa Ferreira, "Noticiário Maranhense" [1688?], Revista do Instituto Histórico e Geográfico Brasileiro, vol. 81, 1917, p. 289-352; 344. Notas: 1) a fonte de 1637 acrescenta ainda ao total de moradores 60 soldados em São Luís, 50 em Belém, 30 soldados no forte do Ceará (onde também viveriam quatro ou cinco moradores) e no forte do Gurupá menos de 30 soldados sem nenhum morador; 2) ao total de vizinhos de São Luís em 1685, acrescentem-se 150 soldados e, em Belém, "200 homens que podem tomar em armas",

${ }^{34}$ Rafael Chambouleyron, "Escravos do Atlântico equatorial: tráfico negreiro para o Estado do Maranhão e Pará (século XVII e início do século XVIII)", Revista Brasileira de História, vol. 26, n. 52, 2006, p. 79-114. 
“fogo", então teríamos em todo o Estado do Maranhão e Grão-Pará uma população de origem portuguesa, nos fins da década de 1660, não superior a seis mil indivíduos e que teria se elevado nas décadas de 1680 e 1690 a algo em torno de dez mil pessoas. A esse total, ainda segundo o mesmo autor, o número de escravos importados talvez não ultrapassasse 1.500 escravos importados entre a década de 1670 e o primeiro decênio do século XVIII. A questão em aberto é, sem dúvida, dispor de algum parâmetro minimamente seguro para mensurar o total da população indígena integrada a esse conjunto, certamente considerável nos aldeamentos missionários. ${ }^{35}$

Em síntese, se para o século XVI, o número de habitantes do Brasil proposto por Contreiras Rodrigues não se afasta de modo importante dos autores que constituem a referência necessária, para o século XVII, o quadro alterase fortemente. Já para 1660, os dados recolhidos em Rocha Pombo não são referenciados a qualquer fonte. O mesmo problema se repete ao se tratar da população tanto dos meados quanto dos fins do século XVII. Uma vez mais, o problema é a ausência de referências fiáveis e a liberdade de "arriscar" as cifras, algumas francamente irreais, como o total de 60 mil escravos em São Vicente. Sem dúvida, isso tudo constitui um exercício estatístico, em larga medida submetido a senões de toda ordem, a primeira das quais, a qualidade das fontes. Mas, pelo menos, permite considerar em bases mais claras o tema da população do Brasil no período anterior ao grande movimento demográfico provocado pela mineração no interior do território.

\footnotetext{
${ }^{35} \mathrm{~A}$ esse respeito, $c f$. as informações, ainda que nada precisas, de Maurício de Heriarte, "Descrição do Estado do Maranhão, Pará, Gurupá e rio das Amazonas", In: Francisco Adolfo de Varnhagen, História Geral do Brasil, vol. 3, São Paulo, Melhoramentos, 1956, p. 189-190.
} 